\title{
THE DISTRIBUTION OF HG ${ }^{203}$-LABELED MERCAPTOMERIN IN HUMAN TISSUES ${ }^{1,2}$
}

\author{
By JERRY K. AIKAWA ${ }^{3}$ AND REGINALD H. FITZ \\ (From the Department of Medicine, University of Colorado School of Medicine, Denver, Colo.)
}

(Submitted for publication December 9, 1955; accepted March 15, 1956)

The availability of a radioactive isotope of mercury, $\mathrm{Hg}^{203}$, and the recent improvements in instrumentation for radioactivity assay obviating loss of mercury through volatilization has made possible a further study of the behavior of an organic mercurial diuretic agent, mercaptomerin sodium (Thiomerin ${ }^{\circledR}$ ). Previous studies in the rabbit (1) have shown that 87 to 96 per cent of the radioactivity administered as $\mathrm{Hg}^{203}$-labeled mercaptomerin can be recovered in the urine, kidney, and liver. Analysis of the entire carcass, urine and feces of a rabbit 24 hours after injection of a tracer dose of $\mathrm{Hg}^{203}$ as labeled mercaptomerin showed that 97 per cent of the total administered radioactivity could be accounted for. Studies in the rabbit (1), rat and dog (2) have shown species differences in the renal excretion of mercury; residual radioactivity was concentrated primarily in the kidney. The concentration of mercury in the renal tissue varied considerably, even in normal healthy rabbits (1). This finding, together with the clinical observation that the diuretic response of human beings to the injection of a standard amount of a mercurial agent cannot be predicted, suggested that there might be considerable variation in the ability of diseased human kidneys to concentrate mercury administered in an organic form and that this variability may be one of the factors contributing to the erratic response to mercurial therapy.

The purpose of the present study was to determine the tissue distribution of $\mathrm{Hg}^{203}$ which had been administered parenterally as labeled mercap-

1 This study was supported in part by grants-in-aid from the American Heart Association and Wyeth Laboratories, and in part under a contract with the U. S. Atomic Energy Commission.

$2 \mathrm{Hg}^{208}$ was obtained from the Oak Ridge National Laboratory, Oak Ridge, Tennessee, on allocation from the U. S. Atomic Energy Commission.

${ }^{3}$ Established Investigator of the American Heart Association. tomerin sodium, ${ }^{4}$ and to compare its distribution in human tissues with that previously observed in rabbits.

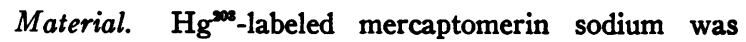
synthesized to contain, per milliliter, $40 \mathrm{mg}$. of mercury in $140 \mathrm{mg}$. of Thiomerin (8), and 140 microcuries of radioactivity. The material was received in a frozen state and stored at $-20 \mathrm{C}$. until immediately prior to use.

Subjects. Patients who were terminally and critically ill and in whom, in the opinion of the house officers and attending staff, no contraindications existed for the injection of tagged mercaptomerin sodium, were given 1 or $2 \mathrm{ml}$. of the material intravenously or subcutaneously. The present report is based on the findings at autopsy in 9 cases. Pertinent clinical data have been summarized in Table $\mathrm{I}$.

Methods. One to 2 gram samples of tissues obtained at autopsy were weighed in 1-dram glass vials, which were then stoppered tightly. These samples were assayed for radioactivity by gamma ray counting in the well of a Nuclear Model DS-3 scintillation counter which was attached to a Tracerlab Superscaler. The concentration of mercury per gram of wet weight of tissues was then calculated from the known specific activity of the tagged Thiomerin 1 .

\section{RESULTS}

Tissues were obtained from subjects who died between $1 \frac{1}{4}$ and 576 hours (24 days) after the administration of tagged mercaptomerin (Table I). Selective concentration of $\mathrm{Hg}^{203}$ in the renal parenchyma had begun as early as $11 / 4$ hours after subcutaneous administration of the tagged Thiomerin ${ }^{\circledR}$ (case 1). In this patient the concentration of mercury in one kidney was 7.55 micrograms per gram at a time when the serum concentration was 7.26 micrograms per milliliter. Ten hours after the intravenous administration of the labeled mercaptomerin (case 2), the renal concentration was three times that in the serum. Appreciable amounts of mercury were detected in the kidneys for as long as 144 and $\mathbf{5 7 6}$ hours after the administration of a single tagged dose.

\footnotetext{
${ }^{4} \mathrm{Hg}^{200}$-labeled mercaptomerin sodium was synthesized by the Wyeth Institute for Medical Research.
} 
TABLE I

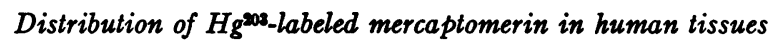

\begin{tabular}{|c|c|c|c|c|c|c|c|c|}
\hline \multirow[b]{2}{*}{ Case } & \multirow[b]{2}{*}{ Initials } & \multicolumn{2}{|c|}{$\mathrm{Hg}^{200}$-Thiomerin (18) } & \multirow{2}{*}{$\begin{array}{l}\text { Time to } \\
\text { death } \\
\text { (hrs.) }\end{array}$} & \multirow[b]{2}{*}{ Primary disease } & \multirow[b]{2}{*}{$\begin{array}{c}\text { Renal lesion } \\
\text { (Microscopic diagnosis) }\end{array}$} & \multicolumn{2}{|c|}{$\begin{array}{c}\text { Kidney weights } \\
(\mathrm{gms.})\end{array}$} \\
\hline & & $\begin{array}{c}\text { Dose } \\
\text { (mg. Hg) }\end{array}$ & Route & & & & Right & Left \\
\hline $1^{*}$ & $\overline{\mathrm{LH}}$ & 80 & $\mathrm{SC} \ddagger$ & 1.25 & $\begin{array}{c}\text { Arteriosclerotic } \\
\text { heart disease }\end{array}$ & $\begin{array}{l}\text { Nephrosclerosis, } \\
\text { arterial moderateई }\end{array}$ & 140 & 150 \\
\hline $2 \dagger$ & CD & 40 & IV & 10 & $\begin{array}{l}\text { Meningococcemia } \\
\text { meningococcic } \\
\text { meningitis }\end{array}$ & $\begin{array}{l}\text { Nephrosclerosis, } \\
\text { arterial, mild\& }\end{array}$ & 130 & 190 \\
\hline 3 & NH & 40 & IV & 24 & $\begin{array}{l}\text { Arteriosclerotic } \\
\text { heart disease; } \\
\text { anuria }\end{array}$ & $\begin{array}{l}\text { Nephrosclerosis, } \\
\text { advanced }\end{array}$ & 90 & 85 \\
\hline 4 & EB & 80 & IV & 36 & $\begin{array}{l}\text { Myocardial in- } \\
\text { farction recent }\end{array}$ & Nephrosclerosis, & 165 & 150 \\
\hline 5 & DW & 80 & IV & 36 & $\begin{array}{l}\text { Acute lymphatic } \\
\text { leukemia }\end{array}$ & $\begin{array}{l}\text { Left, pyelonephritis, } \\
\text { chronic } \\
\text { Right, compensatory } \\
\text { hypertrophy }\end{array}$ & 270 & 60 \\
\hline 6 & $\mathrm{JD}$ & 40 & IV & 48 & $\begin{array}{l}\text { Agranulocytosis; } \\
\text { peritonitis, } \\
\text { generalized }\end{array}$ & Normal & 190 & 180 \\
\hline 7 & LS & 80 & $\mathrm{SC}$ & 48 & Carcinoma of & Pyelonephritis, & 160 & 160 \\
\hline 8 & ER & 80 & IV & 144 & $\begin{array}{l}\text { Rheumatic heart } \\
\text { disease }\end{array}$ & $\begin{array}{l}\text { Nephrosclerosis, } \\
\text { arterial, minimal }\end{array}$ & 190 & 170 \\
\hline 9 & DL & 40 & $\mathrm{SC}$ & 576 & $\begin{array}{l}\text { Cor pulmonale; } \\
\text { duodenal ulcer } \\
\text { with hemorrhage }\end{array}$ & Normal & 145 & 160 \\
\hline
\end{tabular}

* Case 1: Thyroid $=0.85 \mu \mathrm{g} . \mathrm{Hg}$ per gm.; bladder $=0.44 \mu \mathrm{g}$. per $\mathrm{gm}$.

+ Case 2: Bone $=0.74 \mu \mathrm{g}$. per gm.

† $\mathrm{SC}=$ subcutaneous injection; IV = intravenous injection.

Vascular changes considered by pathologist to be not unusual for age of patient and to not imply significantly altered renal function.

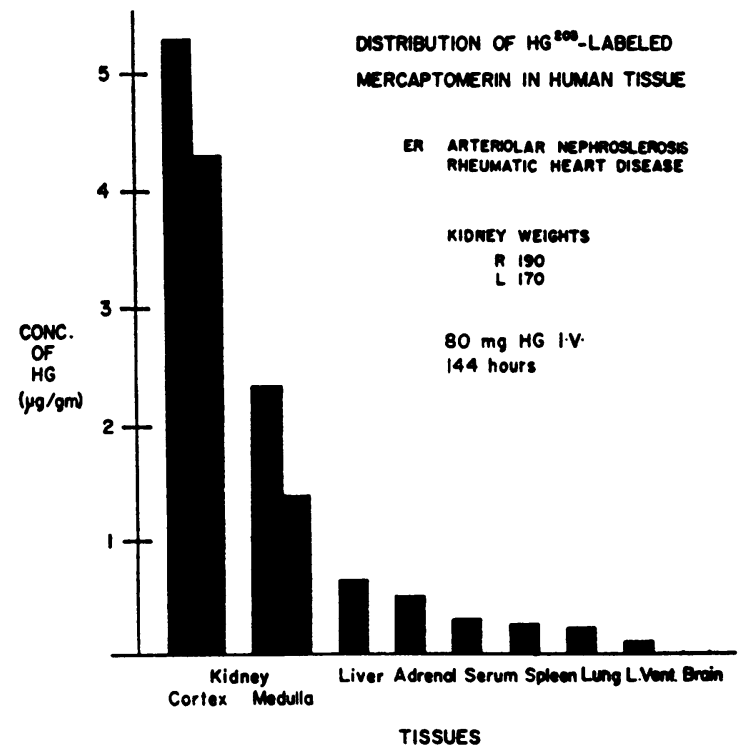

Fig. 1. Case 8, Table I

Note the relative tissue distribution and the renal concentration of radioactivity. The cortex contained more radioactivity than the medulla.
In most instances, the concentration in the kidneys was approximately three times higher than that in the liver-the tissue with the next highest concentration. Tissue from cortex contained approximately twice as much mercury per gram as that from medulla (case 8, Figure 1). The concentration of mercury in brain and bone was negligible, and the values in the other tissues were intermediate between those in the kidney and those in brain and bone.

In general, the concentrations of mercury attained in the two kidneys were roughly equal; the one exception was in a patient (case 5, Figure 2) who at autopsy was found to have one pyelonephritic kidney weighing $60 \mathrm{gm}$. and one hypertrophic kidney weighing $270 \mathrm{gm}$. The concentration of mercury in the latter (26.16 micrograms per gram) was over twice that in the smaller organ (11.81 micrograms per gram). The highest renal concentration of mercury (69.86 micrograms per gram) was found in the subject (case 4) who 
TABLE I-Continued

\begin{tabular}{|c|c|c|c|c|c|c|c|c|c|}
\hline \multicolumn{3}{|c|}{$\begin{array}{l}\text { Concentrations of mercury } \\
\text { (us. } \mathrm{Hg}_{\mathrm{g} / \mathrm{gm} \text {. wet weight) }}\end{array}$} & \multirow{2}{*}{$\begin{array}{l}\text { Skeletal } \\
\text { muscle }\end{array}$} & \multirow{2}{*}{$\begin{array}{c}\text { Left } \\
\text { ventricle }\end{array}$} & \multirow[b]{2}{*}{ Lung } & \multirow[b]{2}{*}{ Spleen } & \multirow[b]{2}{*}{ Brain } & \multirow[b]{2}{*}{ Colon } & \multirow[b]{2}{*}{ Liver } \\
\hline Serum & Kidney & Adrenal & & & & & & & \\
\hline 7.26 & $\begin{array}{l}6.33 \| \\
7.55\end{array}$ & 1.63 & 1.48 & 1.06 & 1.88 & 1.18 & 0.11 & 1.08 & 2.30 \\
\hline \multirow[t]{3}{*}{2.78} & $\begin{array}{l}8.42 \\
9.38\end{array}$ & & & 0.80 & 1.73 & 0.90 & 0.16 & & 1.75 \\
\hline & $\begin{array}{l}1.92 \\
1.24\end{array}$ & & & 0.80 & & 0.98 & & 1.23 & 2.18 \\
\hline & 69.86 & & & & 3.09 & & & & 2.82 \\
\hline \multirow[t]{3}{*}{5.44} & 11.81 & 3.73 & 2.11 & 1.41 & 7.77 & 6.32 & & & 4.98 \\
\hline & 26.16 & & & & & & & & \\
\hline & $\begin{array}{l}6.82 \\
5.10\end{array}$ & & & & & & & & \\
\hline 0.91 & 16.62 & . & & & 1.29 & 0.61 & & 1.33 & 1.78 \\
\hline 0.29 & $\begin{array}{c}\text { Cortex } \\
5.31 \\
4.30 \\
\text { Medulla } \\
2.33 \\
1.38 \\
9.03 \\
6.45\end{array}$ & 0.50 & & 0.11 & 0.22 & 0.26 & $\mathbf{0}$ & & 0.90 \\
\hline
\end{tabular}

|| Values from both kidneys when available.

died of an acute myocardial infarction and in whom there was no history of previous renal disease and postmortem findings revealed only very mild arterial nephrosclerosis. The lowest renal concentrations (1.92 and 1.24 micrograms per gram) were found in a patient with far-advanced nephrosclerosis (case 3, Figure 3) who was anuric for the 24 hours preceding death. In this subject, 24 hours after injection of the $\mathrm{Hg}^{203}$-labeled mercaptomerin, the mercury concentration in the kidneys was less than that in the liver.

\section{COMMENT}

Measurements of the total mercury content of the kidneys and other tissues at autopsy have been reported in previous studies on the renal toxicity of mercuric chloride (3) and organic mercurial diuretic agents $(4,5)$. The kinetics and localization of mercury administered as a single dose of diuretic can be traced by the use of the radioisotopic technique.

The results of the present radioisotopic study indicate that the renal concentration of mercury following the parenteral administration of one dose of tagged mercaptomerin varies widely in magnitude and duration in different subjects. The con-

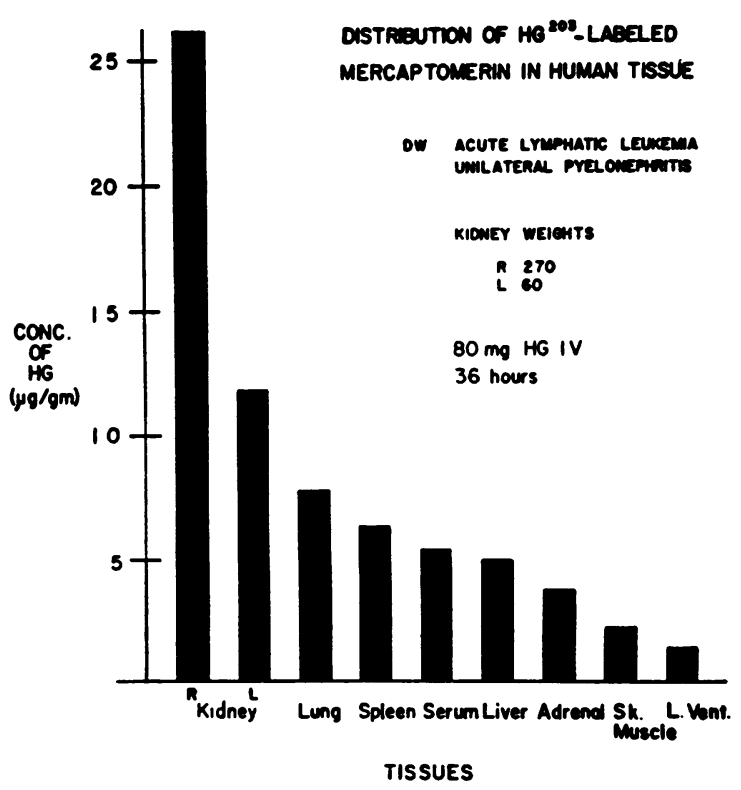

Fig. 2. Case 5, Table I

The atrophic left kidney contained less radioactivity than the hypertrophied right kidney. 


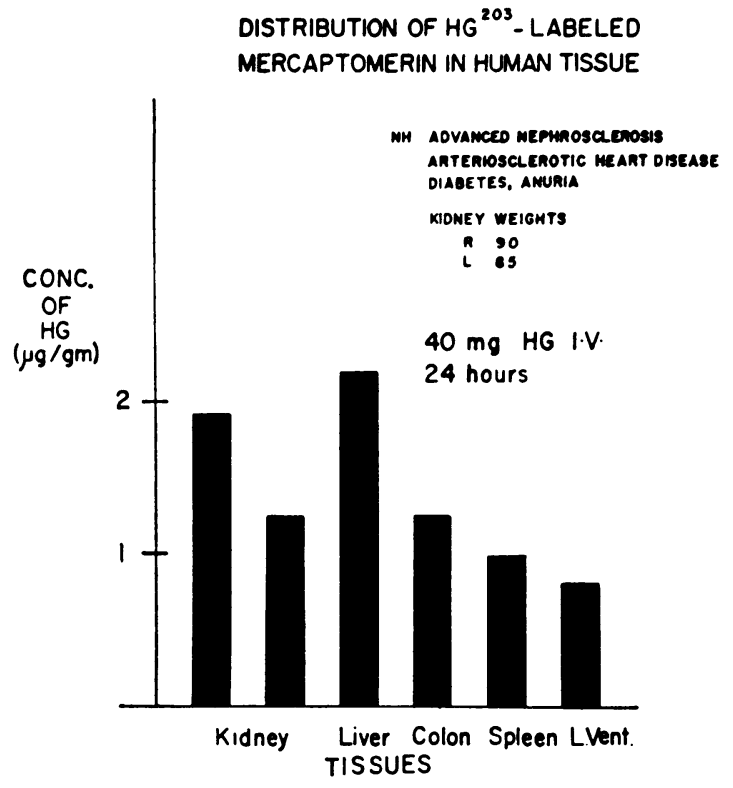

Fig. 3. Case 3, Table I

Both kidneys were abnormally small and concentrated mercury least of the nine cases studied.

centrations of mercury in the various tissues within the first 48 hours after injection were as much as ten times higher than those observed previously in normal rabbits given an equivalent dose of labeled mercaptomerin (1), and approached the values reported by Adam (6) following the administration of $\mathrm{Hg}^{203}$-tagged mercuric chloride to normal rabbits in doses of $1 \mathrm{mg}$. per kilogram. These comparative results suggest considerable differences of behavior of mercaptomerin in different species; Pitts and Borghgraef (2) have found that the degree of renal binding of Neohydrin ${ }^{\circledR}$ differs in the rat and dog.

The highest renal concentration of mercury was found in the subject who died of an acute myocardial infarction, and who had minimal arterial nephrosclerosis at autopsy. The anuric subject with little functional renal parenchyma showed the lowest concentration. These observations, as well as the difference in the concentrations of mercury between the pyelonephritic and the hyper- trophied kidneys of patient 5, suggest that the ability of the organ to concentrate mercury depends at least partially upon the quantity and quality of the functional tissue. The higher concentration of mercury in the renal cortex, as compared with the medulla, is consonant with the view that the organic mercurial agents localize primarily in the distal or proximal tubules (7).

\section{SUMMARY}

Forty to $80 \mathrm{mg}$. of mercury as $\mathrm{Hg}^{203}$-labeled mercaptomerin sodium was administered parenterally to 9 terminally ill patients, and tissue analyses were performed $1 \frac{1 / 4}{4}$ to 576 hours later at autopsy. In all cases the kidneys were found to contain mercury. The highest concentration was 70 micrograms per gram of wet tissue; most of the values ranged between 1.2 and 9.4 micrograms per gram. The concentration appeared to be dependent upon the quantity and the quality of the renal parenchyma.

\section{REFERENCES}

1. Aikawa, J. K., Blumberg, A. J., and Catterson, D. A., Distribution of $\mathrm{Hg}^{208}$-labeled mercaptomerin in organs of normal rabbits. Proc. Soc. Exper. Biol. \& Med., 1955, 89, 204.

2. Pitts, R. F., and Borghgraef, R., Binding of a radiomercurial diuretic in the kidney in relation to diuresis. Federation Proc., 1955, 14, 115.

3. Sollmann, T., and Schreiber, N. E., Chemical studies of acute poisoning from mercury bichloride. Arch. Int. Med., 1936, 57, 46.

4. Forney, R. B., and Harger, R. N., Mercury content of human tissues from routine autopsy material. Federation Proc., 1949, 8, 292.

5. Butt, E. M., and Simonsen, D. G., Mercury and lead storage in human tissues, with special reference to thrombocytopenic purpura. Am. J. Clin. Path., 1950, 20, 716.

6. Adam, K. R., The effects of dithiols on the distribution of mercury in rabbits. Brit. J. Pharmacol., 1951, 6, 483.

7. Mustakallio, K. K., and Telkkä, A., Histochemical localization of the mercurial inhibition of succinic dehydrogenase in rat kidney. Science, 1953, 118, 320. 